\title{
Invitations and excuses that are not invitations and excuses: Gossip in Luke 14:18-20
}

\begin{abstract}
Author:
Ernest van Eck ${ }^{1}$

Affiliation:

${ }^{1}$ Department of New

Testament Studies, University

of Pretoria, South Africa

Correspondence to:

Ernest van Eck

Email:

ernest.vaneck@up.ac.za

Postal address:

TPS 15, Box 12320, Hatfield

0027, South Africa

\section{Dates:}

Received: 13 Mar. 2012

Accepted: 14 Apr. 2012

Published: 15 Aug. 2012

How to cite this article:

Van Eck, E., 2012, 'Invitations

and excuses that are not invitations and excuses:

Gossip in Luke 14:18-20', HTS Teologiese Studies/

Theological Studies 68(1),

Art. \#1243, 10 pages. http://

dx.doi.org/10.4102/hts.

v68i1.1243
\end{abstract}

(C) 2012. The Authors.

Licensee: AOSIS

OpenJournals. This work

is licensed under the

Creative Commons

Attribution License.
In modern Western culture, gossip is seen as a malicious activity that should be avoided. In ancient oral-cultures, gossip as a cultural form did not have this negative connotation. Gossip was a necessary social game that enabled the flow of information. This information was used in the gossip network of communities to clarify, maintain and enforce group values, facilitate group formation and boundary maintenance and assess the morality of individuals. Gossip was a natural and spontaneous recurring form of social organisation. This understanding of gossip is used to interpret the two invitations and three excuses in the parable of the Feast (Lk 14:16a-23). The conclusion reached is that gossip, when understood as a social game, can be a useful tool to curb anachronistic and ethnocentristic readings of texts produced by cultures different from that of modern interpreters analysing these texts.

\section{Introductory remarks}

Parable scholars interpret the double invitation in the parable of the Feast more or less unanimously. The purpose of the first invitation is to give invited guests ample notice of a meal that is going to take place, an invitation that requests an answer to enable the host to prepare a proper meal for a known number of guests. The purpose of the second invitation, extended only to those who accepted the first invitation, is to let the guests know that the feast is ready. The interpretation of the three excuses (Lk 14:18-20), focusing on their content, shows a wide array of opinions. The dominant view is that the excuses are spurious, flimsy and invalid.

In this contribution, the interpretations of these invitations and excuses in the parable are assessed through the lens of gossip as a cultural form or social game (a catalyst of social process). Attention is first given to gossip as understood and practised in oral cultures, that is, the culture in which the parable was told. This understanding of gossip is then used to interpret the invitations and excuses in the parable as an example of what constitutes a 'gossip event'. Attention is also given to the identification of the host and invitees as far as the information in the parable allows. It is argued that the first invitation is an honour challenge, that gossip takes place in the time between the first and second invitation, resulting in three excuses as riposte to the challenge embedded in the first invitation. In the analysis of the excuses, the focus is not on the content of the excuses but on what lies behind them. The conclusion reached is that the invitations and excuses are not invitations and excuses in the modern sense of the word. Gossip, as a heuristic tool, enables the reader to avoid this anachronistic and ethnocentric reading of the invitations and excuses in the parable.

\section{Gossip}

The term gossip, from our modern or Western perspective, is normally used in a pejorative sense, referring to the 'undesirable, sometimes malicious activity engaged in by persons who have nothing better to do than to pass along unsubstantiated information about others' (Arno 1980:344; see also Spacks 1982:19-38). ${ }^{1}$ In the majority of oral (non-literate) cultures, gossip does not necessarily have this pejorative meaning since gossip is often the only way of obtaining information (Malina \& Rohrbaugh 1998:103; Paine 1967:282). Gossip is understood in its cultural form as a 'sort of game' (Gluckman 1963:307), a 'catalyst of social process' (Paine 1967:283), a necessary and positive social activity of informal social bonding and formation, control and order (Abrahams 1970:296; Gluckman 1963:307; Paine 1967:278).²

1.Jaworski and Coupland's definition of gossip is another example of how gossip is understood in most modern societies: 'As a starting point, we take gossip to be talk about people and their personal lives that involves some kind of newsworthy element and some form of (usually) pejorative evaluation ... gossip is linked with "bad," "nasty," or otherwise highly critical talk about others, usually absent third parties, and with "women's language"' (Jaworski \& Coupland 2005:667-668). See, however, Spacks who argues that gossip in modern societies is not always malicious, idly destructive, self-aggrandising, false and the expression of individual envy and aggression; gossip can also serve as 'healing talk' that builds intimacy and comradeship, and at times can serve as instruction (Spacks 1982:26-28, 38).

2.This does not mean that gossip is not also prevalent in written comments, as illustrated by Rohrbaugh (2001:242) with examples from the New Testament (e.g. 1 Cor 1:11; 7:1; 8:1 and 12:1). Gossip is also not limited only to oral cultures that can be considered as 'ancient'. As the studies of Colson (1953; the Makah Indians of Neah Bay on Cape Flattery), Gilmore (1978:89-99; Fuenmayo in Andalusia), Andreassen (1998:41-56 Henningsvær in Norway) and Hames (2003:351-364; Sucre in Bolivia) have shown, gossip as cultural form is also prevalent in some 'modern' oral cultures. See also Wickham's study of gossip among the medieval peasantry in Tuscany (Italy) - where publica fama (common knowledge) is constituted through gossip - and Iceland and Montaillou (a village in the French Pyrenees) that identifies the important role gossip played in these communities (Wickham 1998:3-24). It seems that gossip assists the flow of information especially in societies that lack organised news media (Ober 1996:148) 
Although gossip is indeed a universal phenomenon, several anthropological studies indicate that gossip was (and still is) prevalent in the Mediterranean region (Rohrbaugh 2001:240). ${ }^{3}$ The reason for this prevalence is that gossip seems to play 'a different role in non-literate societies than in literate ones, not only in scope and impact, but also in shape and social function' (Rohrbaugh 2001:240). In nonliterate societies, gossip is an institutionalised means of informal communication, interwoven in the daily affairs and interactions between people; everybody partakes in it, and it is not necessarily seen as malicious (Andreassen 1998:41).

\section{Gossip: Definition, characteristics and social function}

Gossip, as a cross-cultural phenomenon, is studied by most anthropologists from either a functional or a transactional perspective. These two perspectives are seen by some anthropologists as mutually exclusive (see e.g. Paine 1968:305-308), although both positions 'consider as non-problematical the actual process by which gossip is passed from one person to another' (Handelman 1973:210). According to the first perspective, developed by Gluckman $(1963,1968)$, it is the community that gossips: Gossip is a spontaneous collective sanction, a public opinion enforcing conformity to community norms, and 'it is a group-binding, boundary-maintaining mechanism' (Gilmore 1978:89). The second perspective, developed by Paine $(1967,1968)$ in reaction to Gluckman, sees gossip as an action not of the community but of individuals: Gossip is 'not a mechanism of social control but a form of information-communication' (Gilmore 1978:89; see also Daniels 2008:12-14; Handelman 1973:210; Malina \& Rohrbaugh 1998:103; Paine 1967: 278-279; Wilson 1974:93).

As Gilmore (1978:89-99) has indicated, these two perspectives are not mutually exclusive. The difference between Gluckman and Paine is that of different forms of gossip, and it does not concern gossip as a general category (Gilmore 1978:98; see also Wilson 1974:93). Gluckman focuses on collective gossip, and Paine focuses on small-group gossip. Both of them are correct in their characterisation of gossip. The difference between

3.See Rohrbaugh (2001:239-256) for an insightful discussion of gossip in the Mediterranean by making use of the studies of Arno (1980:343-360), Bailey (1971), Campbell (1964), Du Boulay (1974), Gilmore (1978:89-99, 1982:175-205, 1987), Gluckman (1963:307-316), Goldsmith (1989:163-169), Paine (1967:278-285) and Yerkovich (1977:192-197). In this contribution, Rohrbaugh takes as point of departure the important remark of Gluckman (1963:307), namely that gossip and scandal are 'among the most important societal and cultural phenomena we are called upon to analyse'. He also refers to Radin, who indicated that 'primitive people are indeed among the most persistent and inveterate of gossips. Contestants for the same honors, possessors of the sacred rites of the tribe, the authorized narrators same honors, possessors of the sacred rites of the tribe, the authorized narrators
of legends, all leave you in little doubt as to the character and proficiency of their of legends, all leave you in little doubt as to the character and proficiency of their bandied about' (Radin 1957:177-178, cited by Rohrbaugh 2001:240, note 1). For the Mediterranean as geographical and cultural subspecialty in social and cultural anthropology, see Boissevain (1979:81-93), Davies (1977) and Gilmore (1982:175-205). In this regard, Rohrbaugh (2001:240) makes the following important remark: 'Of course gossip has not been the same in all Mediterranean societies at all times in history, and therefore we cannot assume that gossip in Greek villages today is the exact equivalent of gossip in the Greek villages of antiquity. But ethnographers argue that several lasting features of Mediterranean culture have had a marked impact on gossip there and hence these must be taken into account'.

4. Handelman (1973:210) describes the functionalist position as concentrating 'on explicating the latent functions of gossip in various social units', whilst the transactionalist position stresses 'how particular persons tactically utilise gossip for purposes of impression-management or information-management to further their rather explicit aims.' these two perspectives is mere semantics (Gilmore 1978:98) or the use of different explanatory approaches focusing on different elements of gossip (Bergman 1993:139-149). Gossip as a 'general category is not one thing or the other, but a diverse range of behaviours all of which have something in common' (Gilmore 1978:89). It is 'the informal circulation of information about and evaluation of people's behaviour ... concerned not with a single type of verbal interaction but with a set of interrelated types' (Arno 1980:244).

Gossip as 'a naturally recurring form of social organisation' (Handelman 1973:212) or 'cultural form' (Spacks 1985:15) can, in short, be defined as conversations or critical talk about absent third parties (see Gilmore 1987:92; Haviland 1977:28; Hunter 1990:300; Lancaster 1974:2625). This definition implies the following characteristics of gossip:

- Gossip is 'signed' or face-to-face-talk about people who are not present, which implies that at least three parties are always part of a gossip event: the gossiper, the party listening and the gossipee (Rohrbaugh 2001:241). ${ }^{6}$ Gossip takes place 'in small groups, ones which include neither the talked-about person nor anyone who would report the conversation to him' (Abrahams 1970:300). Gossip is thus private and intimate (Arno 1980:343; Merry 1984:276).

- For gossip to occur, it requires that participants know each other, to understand the import of the situation and to share evaluative categories (Yerkovich 1977:192). As put by Abrahams (1970):

Gossip, like joking, takes place between individuals who stand in a special relationship to each other. We can therefore discern a good deal of the formal and informal social structure of a community by noting those categories of people who joke or gossip with each other. Furthermore, like joking, both the content and forms of gossip are traditional, and it is these conventional aspects which define and restrict the communicative situation. ${ }^{7}$ (p. 290)

- Gossip overlaps with simple word-of-mouth 'news' about what is going on (Rohrbaugh 2001:241) and is often the principle means of information exchange in non-literate villages (Arno 1980:343; Paine 1967:282).

- Gossip is evaluative talk. It may be either positive or negative, but it usually implies assessment of one kind or another (Rohrbaugh 2001:241). Assessment takes place in terms of traditional norms, values and ideologies

5.Lancaster (1974:262) defines gossip as follows: 'The structure of the situation in which gossip takes place is that between two individuals or groups, A and B, about a third individual or group, C, who is not present.' The following definition of Daniels is more extensive and noteworthy since it incorporates the characteristics, social function, reason and aim of gossip as a social game: 'Gossip is face-to-face communication involving at least two persons, two groups, or a single group, communication involving at least two persons, two groups, or a single group,
engaged in transacting information, either positive or negative in character, about a third-party subject who is either actually absent or rendered absent to the conversation. A gossip encounter occurs as a response to a generative event, or reports such an event, that undercuts or challenges the established social-cultura expectations of persons, in an attempt to (re)assert or (re)construct reality' (Daniels 2008:38-39).

6.Arno (1980:343) typifies this aspect of gossip as 'three-cornered': Gossip is not a direct struggle between rivals or competitors, but 'a three-cornered one in which each antagonist tries to win the support of a third party embodied as public opinion'. Handelman (1973:210) calls this characteristic of gossip 'the encounter'.

7.See also Merry (1984:277) who describes this characteristic of gossip in the same manner: 'Typically an informal type of personal communication, gossip flourishes in close-knit, highly connected social communities and facilitates social bonds between group members'. Gossip, therefore, 'has much to tell about the society that produced it' (see Hunter 1990:299). 
(Andreassen 1998:42), and it is not necessarily malicious (Andreassen 1998:41). ${ }^{8}$ It is, as formulated by Gluckman (1963:312), 'a culturally controlled game with important social functions ... gossip is not idle: it has social functions and it has rules which are rigidly controlled' (see also Hunter 1990:300).

- Gossip normally serves the interests of individuals (selfinterest) and the groups to which individuals belong (Rohrbaugh 2001:241). Gossip is used by the gossiper either to increase the gossiper's base of esteem or to articulate interactional channels such as friendship networks. It is used to maintain and demonstrate friendship (Abrahams 1970:291, 296).

- One of the main causes of gossip is the intense competition for public reputation (honour; Rohrbaugh 2001:245) and community status (personal power; Abrahams 1970:292).

These characteristics imply several social functions of gossip as a controlled cultural form. Rohrbaugh (2001:251-256) identifies the following four social functions of gossip (see also Malina \& Rohrbaugh 1998:103):

- Clarification (consensus building), maintenance (reaffirmation) and enforcement (sanction) of group values: Gossip reinforces and re-asserts group values. Suls (1997:165, in Rohrbaugh 2001:251) explains it as follows:

Where community consensus on moral standards is lacking ... and where people begin to take sides on a matter of individual conduct, gossip about the 'others' frequently becomes a campaign in which one side seeks social control (see also Abrahams 1970:299; Malina \& Rohrbaugh 1998:103; Rosaldo 1989:315; Paine 1967:279).

Rohrbaugh (2001) also claims the following:

As people comment on or condemn the failings of others, they reinforce behavioral norms. Conformity to the norms develops social reputation and thus competition for honor places sharp controls on individual behavior. ${ }^{10}$ (p. 252)

In short, gossip is the practice of talking about other people's business as a technique for maintaining community control through the elucidation of a public morality' (Abrahams 1970:290; see also Wickham 1998:1112, 18). ${ }^{11}$ Gossip can thus be typified as 'a processual feature of interpersonal behaviour which mediates

8.'[i]t is possible to show that among relatively small groups, gossip, in all its very many varieties, is a culturally determined process, which has its own customary rules, trespass beyond which is heavily sanctioned ... gossip, and even scandal, have important positive virtues. Clearly they maintain the unity, morals and values of social groups. Beyond this, they enable these groups to control the competing cliques and aspiring individuals of which all groups are composed. And finally, they make possible the selection of leaders without embarrassment' (Gluckman 1963:308).

9. Hunter (1990:299-300) describes these salient aspects of gossip as follows: 'As a "cultural form" ... gossip is expressive of the norms, values, and ideology of a given community and of the larger society of which that community is a part ... [G]ossip as a mode of oral communication flourishes where contact is close and experience shared and where private, even intimate, matters are transmitted through a common grapevine, of neighbours, for example ... For gossip is about reputation. While asserting the common values of the group, it holds up to criticism, ridicule or abuses those who flout society's or the community's accepted rules. Thus gossip functions as a means of social control, ensuring, through its sanctions, conformity with those rules.'

10.See also Gluckman (1963:313): 'The values of the group are clearly asserted in gossip and scandal, since a man or woman is always run down for failing to live up to these values.'

11.James West, as early as 1945 , connected gossip with the maintenance of the unity of groups and their morality. His anthropological study of a rural community in the USA indicates that the control of morals operates mainly through gossip and the fear of gossip (see Gluckman 1963:308). between conflicting principles' (Abrahams 1970:296) ${ }^{12}$, an informal system used to evaluate norms, values and the action of others (Arno 1980:343; Merry 1984:276) and the legitimising of social behaviour (Scott 1993:7). Gossip is therefore normally rife in times of social change in order to protect and reassert traditional cultural ways (Andreassen 1998:42) or when there is anxiety but inadequate knowledge about innovative ideas (Rogers \& Svenning 1969:295).

- Group formation and boundary maintenance: Gossip clarifies group membership by re-affirming who is 'in' and who is 'out', thus differentiating between insiders and outsiders (Malina \& Rohrbaugh 1998:103; Rohrbaugh 2001:253). Gossip unites 'a group within a larger society, or against another groups'. Gossip is thus a powerful means of social inclusion and exclusion or group identity (Andreassen 1998:42; Campbell 1964:314; Cutileiro 1971; Jaworski \& Coupland 2005:667; Rysman 1977:64-68; Wickham 1998:10, 11, 14)..$^{13}$ The 'more exclusive the membership of a group, the more prevalent gossip is likely to be among the members' (Rohrbaugh 2001:253) ${ }^{14}$. Persons belonging to a higher status group therefore constantly talk about how they are differentiated from those beneath them (Rohrbaugh 2001:253). In short, gossip 'becomes a form of boundary maintenance' (Zinovieff 1991:122, in Rohrbaugh 2001:253). 'It provides social inclusion: if someone gossips to you about somebody else, you fit in' (Scott 1993:7). As such, it provides connectedness with people and sets social parameters (Scott 1993:7; see also Andreassen 1998:41; Gluckman 1963:31; Hunter 1990:321-322). ${ }^{15}$

- Moral assessment of individuals: 'Because moral assessment is the very nature of gossip, it allows gossipers to rank people in relation to others on an ongoing basis' (Du Boulay 1974:211, in Rohrbaugh 2001:254). People in the Mediterranean use gossip to measure others and themselves on the scale of community values (Rohrbaugh 2001:254; see also Abrahams 1970:290; Herskovits 1937:7476; Rysman 1977:64-68).

- Leadership identification and competition: Since leaders in the Mediterranean are identified as those who embody group norms, competition between leaders often takes the form of gossip (Rohrbaugh 2001:254, citing Gluckman 1963:308; ${ }^{16}$ see also Arno 1980:343; Paine 1967:278, 280;

12.Arno (1980:343), in referring to Szwed, Paine and Gluckman, defines this aspect of the social function of gossip as follows: 'Gossip is a system for the circulation of information about, and the evaluation of, behavior among members of a group ... At the same time, it is used to "forward and protect individual interests" ... Gossip not only maintains group boundaries but also serves as a weapon used by Gossip not only maintains group boundaries but also
individuals in intragroup competition and conflict.'

13.See also Colson (in Gluckman 1963:311): '[S]pecific and restricted gossip within a group marks it off from other groups, both like and unlike.' This is also the point of view of Wickham (1998:23): 'Gossip articulates and bounds identity, group memory and legitimate group social practice ... It represents the recreation of the structures of that group, and of society in general, at the level of consciousness.'

14.See also Gluckman (1963:309): 'The more exclusive the group, the greater will be the amount of gossip in it.

15.See also Paine (1967:270): 'Thus gossip is conceived as a property of the group; its use is regulated by the group in such a way that it serves to demarcate the group and, at the same time, helps to perpetuate it.'

16.It is typical of village life in oral cultures that gossip is used as social tool to evaluate 'people as leaders, as good villagers, and the like, so that gossip also serves to bring, conformity with village values and objectives' (Gluckman 1963:312). This process of gossip 'enables a group, to evaluate people for their work, their qualities process of gossip 'enables a group, to evaluate people for their work, their qualities
of leadership, and their moral character, without ever confronting them to their of leadership, and their moral character, without ever con
faces with failures in any sphere' (Gluckman 1963:313). 
Spacks 1985:4). Negative gossip about leaders in a specific community can sometimes be a form of status degradation ritual and the breaking up of friendships, political alliances or business partnerships (Rohrbaugh 2001:256; Paine 1967:27917). Positive gossip, on the other hand, 'can affirm values in the same way that negative gossip proscribes others. It can create intimacy between friends who develop a closeness over against the one(s) being talked about' (Rohrbaugh 2001:256).

The above characteristics and social functions of gossip imply that gossip will take place where there is agreement on the norms and values of a specific community. Daniels (2008) continues:

Thus, for someone to become the subject of gossip, that one must do something to draw attention to him or herself, usually something that goes against social norms, or undercuts the managed impression of the way things or individuals should be ... [F]or a gossip event to occur there must be an unexpected or unusual event that causes it, at least two persons engaged in the communicative event (gossiper and listener), a third party subject of the gossip, and some sort of social setting where ... persons normally get together to socialize. (pp. 17-18, 30)

\section{Gossip and honour}

The social functions of gossip described above indicate that gossip and status and honour go hand in hand. In oral cultures, gossip reinforces behavioural norms, and conformity to these norms develops social reputation and competition for acquired honour. ${ }^{18}$ Persons with high status and honour therefore constantly talk about how they are differentiated from those beneath them (Rohrbaugh 2001:253; Rosaldo 1989:315). As such, gossip is used as a form of boundary maintenance, providing connectedness with others of the same status and setting social parameters for being 'in' or 'out'. Negative gossip about those who have honour or trying to acquire higher status and honour is thus a form of status degradation, breaking up all kinds of relationships built on honour and status. Positive gossip, in contrast, creates the possibility for acquiring honour and higher status. Rohrbaugh (2001) describes this relationship between gossip and honour as follows:

Gossip is especially important in honor-shame societies where the give and take of challenge-riposte is the means by which gains and losses of (acquired) honor are accumulated. Since honor is always a public matter, the gossip network is the means by which these gains and losses are validated, and since that process is ongoing, as people gossip the relative honor status of group members is constantly being updated. (p. 254)

17.'[G]ossipers are in competition with each other and gossip is one of the ways by which they "manage" their competition' (Paine 1967:279).

18.In the first-century Mediterranean world, the pivotal social value was honour Honour can either be ascribed or acquired. Ascribed honour happens passively through kinship or endowment by notable persons of power (e.g. client king procurator or aristocrat). Acquired honour, in contrast, is the 'socially recognized claim to worth that a person obtains by achievements' (Malina \& Neyrey 1991.28). Honour, as a limited good in the first-century Mediterranean world, was particularly Honour, as a limited good in the first-century Mediterranean world, was particularly acquired by means of the social interaction of challenge and riposte. In the firstcentury Mediterranean world, things of value were available on limited scale (see Malina 1987:162-167), especially honour as pivotal value of this world. Honour therefore was a limited good. People competed fiercely against one another for honour (as limited goods), giving expression to the first-century Mediterranean world as an agonistic (strongly competitive) society (see Malina \& Rohrbaugh 2003:369-372).
The connection Rohrbaugh saw between gossip and honour is supported by the studies of several anthropologists focusing on gossip as a social game of give and take. Contestants for the same honour in primitive oral cultures are among the most persistent and inveterate of gossipers (Radin 1957:77). As such, gossip is inter alia determined by the unceasing competition for reputation or honour (Du Boulay 1974:204). This kind of gossip (i.e. the evaluation and ranking of others) is, according to Bailey (1971:45), often the main subject of gossip and chief pastime of the village. It is, in quoting Gluckman (1963:309), 'one of the chief weapons which those who consider themselves higher in status use to put those whom they consider lower in their proper place.' Competition for honour, social ranking and higher status thus go hand in hand with gossip. As put by Rohrbaugh (2001):

The point, then, is that in the degree to which evaluation or moral judgment is involved, gossip becomes a way of manipulating moral status (acquired honor) or other prospects in the 'interests' of some person or group. (p. 242)

And since 'competition for reputation ... is a matter of honor, and honor is the core value in the Mediterranean world' (Rohrbaugh 2001:243), it is clear that gossip plays a pivotal role in the maintenance of one's honour in the Mediterranean world. Failure of any kind, but especially failure to defend honour, therefore always had been the subject of gossip (Campbell 1964:312, in Rohrbaugh 2001:243).

\section{Gossip in the parable of the feast (Lk 14:16b-23)}

In his insightful contribution on gossip in the New Testament, Rohrbaugh (2001:239-259) identifies three types of New Testament texts having to do with gossip, (1) texts about the topos itself (2) texts which report gossip occurring and (3) texts which are themselves gossip (see Rohrbaugh 2001:258). This contribution suggests that maybe a fourth type of New Testament texts having to do with gossip can be added, namely texts which have as content the result of gossip. One of these texts is the excuses of the three invitees in the parable of the Feast found in Luke 14:18-20.

In this parable, the Lukan Jesus tells a story about a man who is preparing a feast and invites many guests. When the feast is ready, he sends his servant to tell those who were invited to come (Lk 14:16b-17). The invited guests all alike begin to make excuses, giving reasons why they cannot come: The first guest bought a field and had to go to inspect it. The second guest bought five yoke of oxen and was on his way to try them out, and the third guest recently got married, which made it impossible for him to attend. When the servant reports back to his master, the man (host) is upset, becomes angry, and then makes other plans to fill his house (Lk 14:18-23).

The excuses mentioned above become easier to understand for the modern reader if they are seen as the result of gossip (as shall be illustrated below). The preparation of the feast and the invitations and excuses in the parable all have the hallmark of a 'gossip event': The parable has a generative 
event (a feast and invitations); at least two persons or even a group is involved (the persons invited); ample time is available for the transacting of information about the invitation (a time span occurs between the first and second invitation); gossip between the invitees or in the community can take place with an absent third-party (the host); the en masse turning down of the invitation can be understood as a response to an invitation that most probably undercut or challenged the status quo, resulting in the (re)asserting of boundaries, norms and values (see again Daniels 2008:3839), as well as the re-affirmation of the status and honour of the invitees and the shaming of a pretender who has no respect for the status quo.

To argue this point, a more detailed discussion of the host, the feast, the invitees, the invitations and the excuses in the parable (Lk 14:16b-20) is needed.

\section{The host and invitees: Honour and reciprocity}

Although the host of the feast is simply introduced in Luke $14: 16 \mathrm{~b}$ as a certain man (öv $\theta \rho \omega \pi$ ó $\varsigma \tau \varsigma)$, the rest of the parable describes him as a wealthy person. The man has the means

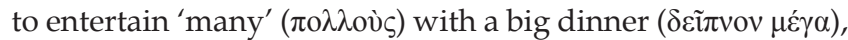
and he has the services of slaves (Lk 14:16b, 17, 20-23). ${ }^{19} \mathrm{He}$ is, as Bailey (1983:94) puts it, a 'great man', referred to as

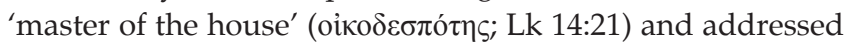
by the mentioned slave in the parable as 'master', 'lord' or 'owner' (кúpros; Lk 14:21, 2, 23). The double invite in the parable further illustrates the man's wealth, since the double invite was a special sign of courtesy practiced by the wealthy (Scott 1989:169). ${ }^{20}$ This description of the host of the feast places him amongst the urban elite, 'a leading member of that urban group which both sets the terms for and controls access to social interaction between itself and others in the society' (Rohrbaugh 1991:140). Finally, if those invited in Luke 14:21 (the people inside the city walls in 'the wider streets and squares' [ $\tau \grave{\alpha} \varsigma \pi \lambda \alpha \tau \varepsilon i \alpha \varsigma$ ] and the 'narrow streets and alleys' [ $\dot{0}$ ' $\alpha \varsigma$ ]), and Luke 14:23 (the people living next to 'the

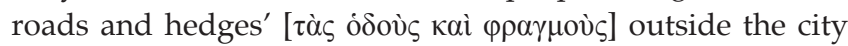
walls; Rohrbaugh 1991:144) are understood as the socially impure (expendables, see Duling 2012:67-71), the host most probably was a Jew.

Who are the invitees of Luke 14:18-20? Regarding the first two invitees, their identity can be deduced by looking at the content of their excuses. The first invitee has acquired a piece of land. No peasant would sell his land if it was not the last resort. Because of taxes (extracted by the elite) and high interest rates on loans (made available by the elite), many peasants in first-century Palestine lost their land or had to sell it (see Van Eck 2009:4-5). Available land normally was bought by the elite, the only ones who had the means to acquire land. Therefore, much of the land outside cities was owned by the elite (see Rohrbaugh 1991:142-143). From this,

19. Although the parable refers to only one slave, it can readily be assumed that more than one slave was needed to prepare the food for the feast and to help in serving
the guests. The man thus most probably had more than one slave (see Schottroff 2007:596).

20.See $\S 3.2$ for a discussion of the double invite in Luke $14: 16 \mathrm{~b}$. one can at least conclude that the face behind the first excuse is an elite person living in the city where the feast is to take place.

The same applies to the person behind the second excuse. According to Jeremias (1972:177), the general size of the land of peasant farmers was more or less 10-20 hectares, which needed 1-2 yoke of oxen to plough. In Luke 14:19, the person has bought five yoke of oxen, which means that the land he owned was at least 50 hectares in size. And, as stated by Rohrbaugh (1991:143), since 'half of the land would have left fallow each year, the owner needing five yoke of oxen is obviously the owner of a very large piece of land'. He is thus part of the elite landowners. ${ }^{21}$

With regards to the invitee that married (Lk 14:20), only indirect inferences can be made. Marriage in the Mediterranean world was always parentally arranged and went hand in hand with honour, status and political and economic concerns (see Van Eck 2007:104-108). The person who married is on the list of those who are invited, and must thus at least have been in the same honour, economic and political league of the other invitees. ${ }^{22} \mathrm{He}$ is therefore most probably also one of the elite. Finally, since all three persons who asked to be excused are from the elite, it can be surmised that the rest of the guests (the 'many' in Lk 14:16b) most probably also are of the same status.

Are the invited guests the host's peers and associates (pace Bailey 1983:94), since he is in the same class, also owning land and cattle (pace Schottroff 2006:52)? There is no information in the parable to make such clear-cut conclusions. To have the forwardness to invite some of the elite in the city as potential guests indeed means that the host must have had some social standing in the community (Funk, Hoover \& The Jesus Seminar 1993:353). What this social standing and honour in the community were is not spelled out in the parable. Most probably, as will be argued below, the problem was that it was not the same of those invited.

The fact that the host invites persons with a specific honour rating to share a meal indicates that he either sees himself as their peer and equal or hopes that by accepting, his guests will affirm his honour rating. In the Mediterranean world, meals taken together were seen as a confirmation of shared values and structures, status and honour rating. Likes only ate with likes (Neyrey 1991:361-387). As put by Taussig (2009):

When people gathered for meals in first-century Mediterranean cultures, the event was laden with meaning. Meals were highly

21.The estimates of the size of land owned by peasants in first-century Palestine by Schottroff and Stegemann and Oakman as well as the size of the land owned by the person who bought five yoke of oxen concur with this conclusion (see Rohrbaugh 1991:143).

22.'Marriages in antiquity were made by extended families, not individuals, and were parentally arranged; they were not agreements between a man and a woman who have been romantically involved ... [I]ndividuals really did not get married. Families did. One family offered a male, the other a female. Their wedding stood Families did. One family offered a male, the other a female. Their wedding stood of both families involved. It would be undertaken with a view to political and/or of both families involved. It would be undertaken with a view to political and/or
economic concerns - even when it may be confined to fellow ethnics, as it was in first-century Israel' (Malina \& Rohrbaugh 2003:28, 240). 
stylized occasions that carried significant social coding, identity formation, and meaning making. Participating in a meal entailed entering into a social dynamic that confirmed, challenged, and negotiated both who the group as a whole was and who the individuals within in it were. (p. 22)

Thus, by accepting the invitation, the guests would have confirmed the honour and status of the host. The 'social dynamic' referred to by Taussig above also relates to what is known as reciprocity, the way in which goods were exchanged in first-century Palestine (Malina 1986:98-106). Reciprocity between equals, known as balanced reciprocity (the idea of quid pro quo), meant that an invitation to a meal was to be followed up by the same kind of invitation to the one who invited a person first. 'A banquet', in short, 'increases the social indebtedness of others to the host' (Scott 1989:169). ${ }^{23}$

\section{The invitations of the host}

Kim (1975:391-402), in a study of Greek invitations on papyri found in Egypt used to invite people to dinners, indicates that the structure and form of these invitations very likely could have been used to invite people to dinners mentioned in the New Testament (Kim 1975:391). Most of the invitations studied by Kim have the same form, including an invitation verb, the names of the invited guest and host, the purpose and occasion of the dinner, as well as the time, date and location of the dinner. These formal invitations, normally written by hosts and then orally conveyed (or read) by messengers, were extended to possible guests some time before the dinner and then followed up with a courtesy reminder (second invitation ${ }^{24}$ ) with the messenger (most probably a slave) escorting the guest(s) to the dinner (Scott 1989:171). A slave arriving to announce that a banquet was ready was a typical Near Eastern custom (Hultgren 2000:333; Hunter 1971:93, 1976:57) and a special sign of courtesy practiced by the wealthy elite (Jeremias 1972:176; Linnemann 1980:87; Perkins 1981:97; Scott 1989:169), and it fits well with the dynamics of the pre-industrial urban system as setting for the parable (Rohrbaugh 1991:141). It can thus be argued that the double invite in the parable is drawn from the life and customs of first-century Palestinian Judaism (Stein 1981:84). ${ }^{25}$

What is the purpose of this double invitation? Parable scholars are more or less unanimous in their answer to this question.

23.Contra Snodgrass (2008:313), who argues that nothing in the parable 'suggests that the host gave his banquet as a quest for honor', although he is also of the opinion that meals in the world of the parable were a means of organising society (see Snodgrass 2008:308).

24.Examples of the first invitation: Chaeremon invites you to dine at a banquet of the Lord Serapis in the Serapeum tomorrow, that is the 15th, from the 9th hour (see Kim 1975:393); 'If the king regards me with favor and if it pleases the king to (sant my petition and fulfill my request, let the king and my petition and fulill my request, Tet the king and Haman come tomorrow to banquet I will prepare for them. Then I will answer the king's question" (Es 5:8; NIV). Examples of the second invitation. "A reminder from your aunt Byrrhena, he said. "You agreed yesterday to dine with her, and it's almost time"' (Apuleius; Metamorphoses 3.12); 'While they were still talking with him, the king's eunuch arrived and hurried Haman away to the banquet Esther had prepared' (Es 6:14; NIV; see Es 5:8 above for the first invitation); 'A person was receiving guests. When he had prepared the dinner, he sent his slaves to invite the guests' (GThom 64:1), See also Midrash Rabbah Lamentations 4.2 that refers to people of Jerusalem of which no one will attend a banquet if not invited twice. Examples that refers to both invitations: 'If thou be invited of a mighty man, withdraw thyself, and so much the more will he invite thee' (Sir 13:9); See also Philo (De Opficio Mundi, XXV.1.78).

25.Contra Crossan (1973:73, 1991:261), who argues that if the plot behind all three extant version of the parable is taken into consideration (i.e., Mt 22:1-14; Lk 14:16 24 and GTom 64:1-12), no firstinvittions were done. The feast was unannounced, and because of the untimeliness of the invitation, the excuses offered are perfectly rean reasonable. See Rohrbaugh (1991:139, 141) for a critique of Crossan's point of view, 'a view that we suggests is a simple but obvious anachronism on the part of modern interpreter with a busy schedule' (Rohrbaugh 1991:141).
The first invitation gives the invited guests ample notice of an occasion that is going to take place and to which they are invited, an invitation they have to respond to (e.g. Crossan 1973:73, 1991:261). As argued by Bailey (1983:94), a host has to prepare for the meal (e.g. proper meat), and for this, the number of guests is needed (see also Lockyer 1963:275). The first invitation helps to know how many people would attend, and how much food has to be prepared (Wenham 1989:136). The first invitation is serious, and 'acceptance of it ... a firm commitment, since the host prepares the amount of food on the basis of how many accepted the invitation' (Bailey 1983:94). Guests who accept the first invitation are duty-bound to appear (Bailey 1983:94; see also Timmer 1999:56). The second invitation is only extended if the first invitation is accepted, which happens at the hour of the banquet (Kistemaker 1980:163). The second invitation thus is 'a courtesy reminder, extended only to those guests who previously accepted the invitation' (Scott 1989:171).

This understanding of the purpose of the double invitation, as will be argued below, is anachronistic, a nice fit of how things are done in the world to which modern interpreters of Biblical texts belong but a poor fit for antiquity. Much more is at stake here, especially when gossip as social game is taken into consideration.

\section{The excuses of the invitees}

The three excuses in Luke 14:18-20 are, unlike the invitations sent by the host, not interpreted unanimously by parable scholars and can be grouped into roughly four positions (with some scholars having more than one opinion).

The first position is that the excuses have to be interpreted in terms of orality and storytelling, in other words, in terms of their intended effect in the parable. According to this position, the excuses are hyperbolic (Weder 1978:187), exaggerated (Funk et al. 1993:352) and absurd (Jeremias 1972:178). This, however, can be explained: Although most unusual, 'in the parables unusual actions such as this are frequently portrayed and would be accepted as part of the storyteller's freedom in telling the story' (Stein 1981:85). The excuses should thus be understood in terms of the rule of good storytelling (Hultgren 2000:336), as evidence of the rule of three and the economy of the parables of Jesus (Snodgrass 2008:306). Also, the use of threes in the parable (the three invitations and three excuses) helps to aid the memory and is evidence that the parable was formulated and passed down orally (Funk et al. 1993:352). In short, the excuses lack verisimilitude and cannot be related to the possibility that all the invited guests, for a specific reason, indeed excused themselves.

A second position sees the excuses as valid, especially when the untimeliness of the invitations is taken into consideration. Crossan (1991:261), for example, opines that the excuses are valid and extremely polite, as does Perkins (1981:97), who claims that the excuses are 'acceptable or at least probable 
excuses in polite form'. Funk et al. (1993:354) interprets the excuses in the same vein: The three invitees refuse for quite legitimate reasons, 'in accordance with the regulations that allow those conscripted to complete essential tasks'. ${ }^{26}$ It seems that these interpretations are built on the premise that only one invitation was extended to the invitees.

The third, and minority position, is that of Linnemann (1980:89). The excuses, Linnemann argues, are not weak excuses. They are rather a notice to the host that the guests will indeed come but that they will be late. After all, one is in the act of buying a field, and another has to go and try out five yoke of oxen. This interpretation is built on the content of the rest of the parable - especially the reaction of the host and his reaction to invite other guests instead - and ignores the third excuse. Also, as will be argued below, this interpretation lacks a close reading of the text.

The fourth and dominant interpretation is that the excuses are flimsy and spurious (Bailey 1983:94; Boice 1983:89; Hultgren 2000:336; Jeremias 1972:179; Kilgallen 2008:84-85; Kistemaker 1980:163; Scott 1989:169; Snodgrass 2008:687; Wenham 1989:136). No one buys a field before inspecting it, buys ten oxen before testing them out, or accepts an invitation to a feast and forgets that he was getting married or spend time with the unimportant sex (a woman) if one can spend it with a man (Bailey 1983:99; Scott 1989:169; Snodgrass 2008:687) - all tasks that could have been done on any other day (Kilgallen 2008:86). The excuses are insulting (Bailey 1983:94; Wenham 1989:136) or even deliberately insulting and extremely offensive. By accepting the first invitation, it becomes a command that has to be honoured (Hultgren 2000:336; Kistemaker 1980:163).

This interpretation of the excuses, first of all, focuses on the content of the excuses, with a typically modern approach to true and false. The social dynamics at play in the parable, however, have less to do with the content of the excuses than with the reason(s) behind them. To be fair, some interpreters do refer to the same spirit and essence of the excuses, namely that it seems that the invitees did not want to go (see e.g. Kistemaker 1980:163; Lockyer 1963: 276-277; Morgan 1953:181-182; Schippers 1962:41; Scott 2001: 109-117). Yet, even if this were the case, the three excuses in the parable are not related to the deafening silence of the other invited guests. The question should not be why the three do not attend the feast, but why everybody turns down the invitation. Secondly, even when one focuses on the content of the three excuses in Luke 14:18-20, the stock interpretation given by most scholars should not simply be accepted on face value. Luke 14:18-20 does not suggest that a field was bought before any inspection, that the five yoke of oxen were not tested out earlier, or that a newly-wed all of a sudden forgot that he was getting married. ${ }^{27}$ Again, this is

26.Funk et al. (1993:354) is not clear on this point. Earlier they state that the excuses are 'most trifling' (see Funk et al. 1993:352).

27.Why is it not also possible that the field had already been inspected before and was now going to be inspected for a specific reason? Maybe the new owner had was now going to be inspected for a specific reason? Maybe the new owner had some work done on the plot he recently bought, like ploughing or the possibility of starting to plough because of the season, moving his sheep from one part of the plot to another to manage grazing, fencing or progress with the erection of dwelling or other project? Why is not consider the possibility that the five yoke of oxen were going to be tried out on a different kind of terrain, with a new driver or plough or even with changing the pairs of oxen around? And why is it not possible not the point. The point is what lies behind these excuses, and why all the invited turned down the invitation. In the third place, these interpretations work with the premise that the first invitation implies a definite yes or no on the part of the invitees, since a number is needed for the preparation of the feast. Thus, what is at play here is common courtesy towards a host, a gesture that will make it possible for a host not to be shamed at a banquet or feast where there is not enough to eat or drink. Who, in our modern society, would like to be part of such an embarrassing situation?

This final and dominant interpretation of the invitations and excuses in the parable, which can be called the 'received view' $^{\prime}$ of the parable, exposes our uncritical lenses when interpreting ancient texts that are the products of cultures vastly different from ours, making such interpretations both anachronistic and ethnocentristic. In an effort to overcome this 'hermeneutical deficit', the excuses in the parable should be understood as the result of gossip as a cultural form or social game that was engrained in the cultural world that produced the parable.

\section{A Mediterranean lens: Excuses as result of gossip}

In oral cultures, like the first-century Mediterranean world, communities, groups and individuals spontaneously gossip as a sort of game, a catalyst of social process that facilitates social bonding, formation, control and order (see § 2). In these cultures, gossip has important social functions of which four were identified, (1) clarification (consensus building), the maintenance (reaffirmation) and enforcement (sanction) of group values (2) group formation and boundary maintenance (3) the moral assessment of individuals and (4) leadership competition and identification in the community. Gossip normally takes place in communities where agreement existed on the norms and values of the community. Thus, when someone does something unexpected or unusual, something that goes against the accepted social norms, such a person becomes the subject of gossip, especially when the honour-rating of the community is at stake. In these communities, honour is a public matter, and the gossip network is the means by which honour status is constantly updated.

The invitations and excuses in the parable are an example par excellence of the social game called gossip. A man formally invites (the first invitation) guests to a feast. This man obviously has an honour rating in the community, as had everybody in the Mediterranean world. What this rating was is not stated. What we do know is that the man must have been part of the elite: He is wealthy enough to entertain many and likely owns several slaves. Since meals are occasions that carried significant social coding and identity formation, the host sees himself as a peer and equal of the invitees, or he

(footnote 27 continues...)

that the third person indeed recently got married, but the marriage feast was extended past the normal feast period of seven days (see Ferguson 1987:55; Malina \& Rohrbaugh 1998:70-71)? Many more reasons can be added to these listed here, equally possible or impossible. The validity or invalidity of these listed here, equally possible or impossible. The validity or invalidity of these
possibilities is just the point: it is not about the content of the excuses, but what possible social dynamics behind the excuses can be identified. 
hopes that by accepting, his guests - who are part of the elite - would affirm either his current honour rating or the rating he aspires to.

The host follows a typical Near Eastern custom practiced by the wealthy elite by extending two invitations to his potential guests. The purpose of the first invitation is neither to give ample notice of an occasion that is going to take place, nor to ascertain the number of guests who will attend. It is also not an invitation that expects an answer; it is an honour challenge to the invited. As put by Rohrbaugh (1991):

A double invitation would have several purposes. Initially the potential guest would have to decide if this was a social obligation he could afford to return in kind. Reciprocity in regard to meals was expected ... But more importantly, the time between the invitations would allow opportunity for potential guests to find out what the festive occasion might be, who is coming, and whether all had been done appropriately in arranging the dinner. Only then would the discerning guest be comfortable showing up. The nearly complete social stratification of pre-industrial cities required keeping social contacts across class lines to a minimum and elaborate networks of informal communication monitored such contacts to enforce rigidly the social code. (p. 141)

What Rohrbaugh clearly implies is that, after this first invitation, the gossip network of the community kicks in. The invitation extended to many is now discussed (gossiped) in the community with the view of clarification, maintenance and enforcement. The host is morally assessed, and boundary maintenance is taking place.

On the day of the feast, the second invitation goes out, not only to those who accepted the first invitation but again to all the invited. Put differently: On the day of the feast, the host in essence inquires about his honour rating in the community. And the answer he receives is not a good one: Peer approval is not forthcoming. This can be deduced from the excuses given to his slave, excuses that are a riposte of the invitees and community to the challenge implied in his first invitation. Again, Rohrbaugh (1991) is insightful:

Their excuses, seemingly irrelevant to the Western, industrialized mind, are standard fare in the dynamics of honorshame societies. The point is not the excuses at hand, but social disapproval of the arrangement being made, a point to which their seeming irrelevance contributes. Something is wrong with the supper being offered or the guests would not only appear, social opinion would demand that they do so. (pp. 141-142)

Thus, what is important is not the content of the excuses, but rather what lies behind them. A few parable scholars have indeed identified this important aspect of the three excuses presented in the parable. Lockyer (1963:276), for example, refers to the similar spirit and essence of the excuses. Scott (1989:171) notes that the excuses have 'the appearance of a concerted effort on the part of those invited', and Plummer (1922:54-56) calls the excuses 'a conspiracy'. Some also agree that with the excuses, the host is effectively snubbed (Scott 1989:169), that the excuses indicate some hostility towards the host on the part of those who were invited because they do not like the host and that the invitees 'boycotted the invitation, likely because of some social impropriety' (Braun, in Swartley 1997:186-187). None of these scholars, however, sees the social dynamics of gossip as a social game as the explanation as the important key to understand the excuses.

With gossip as the interpretative key, the three excuses given in the parable are not the result of the oral transmission of the parable in its pre-literary form following the rule of threes in good storytelling. Also, it does not matter if the excuses are valid or invalid or a notice of latecomers. In the world of the parable, this does not matter at all. What matters is what the excuses convey: The host is shunned. He played the social game according to the rules but does not win the contest - a result of gossip.

Why can this be stated in such categorical terms? Because no one attends the feast - not the three who excused themselves and also not one of the many others invited. The excuses of the three guests represent the outcome of the gossip network operating in the community. Attendance is socially inappropriate. The elite guests play according to the rules, value system and norms of the community:

their excuses conceal the real reason for the disapproval as the system demands. Nor do they break ranks. If one does not show, none do. None will risk cutting himself off from their peers. (Rohrbaugh 1991:143)

\section{Concluding remarks}

What has been gained by the above interpretation of the excuses in Luke 14:18-20? The interpretation, using gossip as a cultural form, removes the anachronistic and ethnocentristic lenses through which modern interpreters sometimes read ancient texts produced by a different cultural system. It indicates that the content of the excuses, the focus of most interpreters of the parable, is not important; what is important is what lies behind these excuses. The interpretation thus shows that gossip, as a tool for social-scientific analysis, has heuristic value.

The interpretation has also shown that the invitations in the parable are not invitations in the modern sense of the word. The first invitation is, in an honour-shame society, an honour challenge and the second an inquiry about one's honour rating. As such, the interpretation has reiterated the important relationship between gossip (public opinion) and honour in the texts produced by a Mediterranean culture. Gossip reinforces behavioural norms, and conformity to these norms develops social reputation and competition for acquired honour. Non-conformity, in contrast, creates shame; as a result of gossip, those who have unrealistic opinions of their own status are put in their proper place. Competition for honour, social ranking, higher status and gossip thus go hand in hand.

Finally, the interpretation suggests that certain texts in the New Testament can perhaps be better understood if they are seen as the result of the social game of gossip.

In the parable, the host, after the first invitees turned down his honour challenge en masse, filled his banquet with persons 
with an honour rating much lower than himself and the initial invitees. It is then when the gossip in the community must really have started. After all, lines had been drawn.

\section{Acknowledgements Competing interests}

The author declares that he has no financial or personal relationship(s) which may have inappropriately influenced him in writing this article.

\section{References}

Abrahams, R.D., 1970, 'A performance-centred approach to gossip', Man 5(2), 290301. http://dx.doi.org/10.2307/2799654

Andreassen, R., 1998, 'Gossip in Henningsvær', Etnofoor 11(2), 41-56.

Arno, A., 1980, 'Fijian gossip as adjudication: A communication model of informal social control', Journal of Anthropological Research 36(3), 343-360.

Bailey, F.G., 1971, Gifts and poisons: The politics of reputation, Blackwell, Oxford.

Bailey, K.E., 1983, Poet and peasant and through peasant eyes: A literary-cultural approach to the parables of Jesus in Luke, William B. Eerdmans Publishing Company, Grand Rapids.

Bergmann, J.R., 1993, Discreet indiscretions: The social organization of gossip, Aldine de Gruyter, New York.

Boice, J.M., 1983, The parables of Jesus, Moody Press, Chicago.

Boissevain, J., 1979, 'Toward an anthropology of the Mediterranean', Currents in Anthropology 20, 81-93. http://dx.doi.org/10.1086/202205

Campbell, J.K., 1964, Honour, family and patronage: A study of institutions and mora values in a Greek mountain community, Clarendon, Oxford.

Colson, E., 1953, The Makah Indians, Manchester University Press, Manchester.

Crossan, J.D., 1973, In parables: The challenge of the historical Jesus, Harper \& Row, New York.

Crossan, J.D., 1991, The historical Jesus: The life of a Mediterranean Jewish peasant, Harper San Francisco, San Francisco.

Cutileiro, J., 1971, A Portuguese rural society, Clarendon Press, Oxford.

Daniels, J.W., 2008, 'Gossip's role in constituting Jesus as a shamanic figure in John's gospel', D.Theol thesis, Department of New-Testament Studies, Unisa.

Davies, J., 1977, The people of the Mediterranean: An essay in comparative socia anthropology, Routledge \& Kegan Paul, London.

Du Boulay, J., 1974, Portrait of a Greek mountain village, Clarendon, Oxford.

Duling, D.C., 2012, A marginal scribe: Studies in the gospel of Matthew in a socialscientific perspective, Cascade Books, Eugene.

Ferguson, E.F., 1987, Backgrounds of early Christianity, Eerdmans, Grand Rapids.

Funk, R.W., Hoover, R.W. \& The Jesus Seminar, 1993, The five gospels: The search for the authentic words of Jesus, Macmillan, New York.

Gilmore, D.D., 1978, 'Varieties of gossip in a Spanish rural community', Ethnology 17(1), 89-99. http://dx.doi.org/10.2307/3773282

Gilmore, D.D., 1982, 'Anthropology of the Mediterranean area', Annual Review of Anthropology 11, 175-205. http://dx.doi.org/10.1146/annurev. an.11.100182.001135

Gilmore, D.D., 1987, Honor and shame and the unity of the Mediterranean, American Anthropological Association, Washington. (Special Publication 22).

Gluckman, M., 1963, 'Gossip and scandal', Current Anthropology 4, 307-316. http:// dx.doi.org/10.1086/200378

Gluckman, M., 1968, 'Psychological, sociological and anthropological explanations of witchcraft and gossip: A clarification', Man 3, 20-34. http://dx.doi. org/10.2307/2799409

Goldsmith, D., 1989, 'Gossip from the native's point of view', Research on Language and Social Interaction 23, 163-194. http://dx.doi.org/10.1080/08351818909389320

Hames, G., 2003, 'Maize-beer, gossip, and slander: Female tavern proprietors and urban, ethnic cultural elaboration in Bolivia, 1870-1930', Journal of Social History 37(2), 351-364. http://dx.doi.org/10.1353/jsh.2003.0180

Handelman, D., 1973, 'Gossip in encounters: The transmission of information in a bounded social setting', Man 8(2), 210-227. http://dx.doi.org/10.2307/2800847

Haviland, J.B., 1977, Gossip, reputation, and knowledge in Zinacantan, University of Chicago Press, Chicago.

Herskovits, M., 1937, Life in a Haitian village, Knopf, New York.

Hultgren, A.J., 2000, The parables of Jesus: A commentary, William B. Eerdmans Publishing Company, Grand Rapids. (The Bible in its world).

Hunter, A.M., 1971, The parables: Then \& now, SCM Press Ltd, London.

Hunter, A.M., 1976, Interpreting the parables, SCM Press Ltd, London.
Hunter, V., 1990, 'Gossip and the politics of reputation in classical Athens', Phoenix 44(4), 299-325.

Jaworski, A. \& Coupland, J., 2005, 'Othering in gossip: "You go out you have a laugh and you can pull yeah okay but like ..."', Language in Society 34(5), 667-694.

Jeremias, J., 1972, The parables of Jesus, Charles Scribner's Sons, New York.

Kilgallen, J.J., 2008, Twenty parables of Jesus in the gospel of Luke, Editrice Pontificio Instituto Biblico, Rome. (Subsidia Biblica 32).

Kim, C.-H., 1975, 'The papyrus invitation', Journal of Biblical Literature 94, 391-402.

Kistemaker, S.J., 1980, The parables: Understanding the stories Jesus told, Baker Books, Grand Rapids.

Lancaster, W., 1974, 'Correspondence', Man 9, 625-626.

Linnemann, E., 1980, Parables of Jesus: Introduction and exposition, 5th edn., SPCK, London.

Lockyer, H., 1963, All the parables of the Bible, Zondervan, Grand Rapids.

Malina, B.J., 1987, 'Limited good and the social world of early Christianity', Biblical Theology Bulletin 8, 162-167.

Malina, B.J., 1986, Christian origins and cultural anthropology: Practical models for biblical interpretation, John Knox Press, Atlanta.

Malina, B.J., 1987, 'Wealth and poverty in the New Testament and its world', Interpretation 41, 354-367.

Malina, B.J. \& Neyrey, J.H., 1991, 'Honor and shame in Luke-Acts: Pivotal values of the Mediterranean world', in J.H. Neyrey (ed.), The social world of Luke-Acts: Models for interpretation, pp. 25-65, Hendrickson, Peabody.

Malina, B.J. \& Rohrbaugh, R.L., 1998, Social science commentary on the gospel of John, Fortress Press, Minneapolis.

Malina, B.J. \& Rohrbaugh, R.L., 2003, Social science commentary on the Synoptic gospels, 2nd edn., Fortress Press, Minneapolis.

Merry, S.E., 1984, 'Rethinking gossip and scandal', in D. Black (ed.), Toward a general theory of social control: Fundamentals, vol. 1, pp. 271-302, Academic Press, Orlando.

Morgan, G.C., 1953, The parables and metaphors of our Lord, Marshall, Morgan \& Scott, Ltd., London.

Neyrey, J.H., 1991, 'Ceremonies in Luke-Acts', in J.H. Neyrey (ed.), The social world of Luke-Acts: Models for interpretation, pp. 361-387, Hendrickson Publishers, Peabody.

Ober, J., 1996, Mass and elite in democratic Athens: Rhetoric, ideology, and the power of the people, Princeton University Press, Princeton.

Paine, R., 1967, 'What is gossip about? An alternative hypothesis', Man 2(2), 278-285. http://dx.doi.org/10.2307/2799493

Paine, R., 1968, 'Gossip and transaction', Man 3, 305-308.

Perkins, P., 1981, Hearing the parables of Jesus, Paulist Press, New York.

Plummer, A., 1922, A critical and exegetical commentary on the gospel according to S., Luke, 5th edn., T \& T Clark, Edinburgh. (International Critical Commentaries).

Radin, P., 1957, Primitive man as philosopher, Dover Publications, Inc., New York.

Rogers, E.M. \& Svenning, L., 1969, Modernization among peasants: The impact of communication, Holt, Rinehart and Winston, New York.

Rohrbaugh, R.L., 1991, 'The pre-industrial city in Luke-Acts: Urban social relations', in J.H. Neyrey (ed.), The social world of Luke-Acts: Models for interpretation, pp. 151-180, Hendrickson Publishers, Peabody.

Rohrbaugh, R.L., 2001, 'Gossip in the New Testament', in J.J. Pilch (ed.), Social scientific models for interpreting the Bible: Essays by the Context group in honor of Bruce J. Malina, pp. 239-259, Brill, Leiden. (Biblical Interpretation Series Volume 53).

Rosaldo, R., 1989, Culture and truth: The remaking of social analysis, Beacon Press, Boston.

Rysman, A.R., 1977, 'Gossip and occupational ideology', Journal of Communication 26, 64-68. http://dx.doi.org/10.1111/j.1460-2466.1976.tb01905.x

Schippers, R., 1962, Gelijkenissen van Jezus, J.H. Kok N.V, Kampen.

Schottroff, L., 2006, The parables of Jesus, transl. L.M. Maloney, Fortress Press, Minneapolis.

Schottroff, L., 2007, 'Von der Schwierigkeit zu teilen (Das Große Abendmahl) - Lk 14,12-24', in R. Zimmermann (eds.), Kompendium der Gleichnisse Jesu, pp. 593603 , Gütersloher Verlagshaus, München.

Scott, B.B., 1989, Hear then the parable: A commentary on the parables of Jesus, Fortress Press, Minneapolis.

Scott, B.B., 2001, Re-imagine the world: An introduction to the parables of Jesus, Polebridge Press, Santa Rosa.

Scott, C., 1993, 'Gossip', Recreation and Leisure 17, 5-7.

Snodgrass, K.R., 1997, 'Anaideia and the friend at midnight (Lk 11:8)', Journal for Biblical Literature 116, 505-513. http://dx.doi.org/10.2307/3266672

Spacks, P.M., 1982, 'In praise of gossip', The Hudson Review 35(1), 19-38. http:// dx.doi.org/10.2307/3851309

Spacks, P.M., 1985, Gossip, Knopf, New York.

Stein, R.H., 1981, An introduction to the parables of Jesus, The Westminster Press, Philadelphia.

Suls, J.M., 1977, 'Gossip as social comparison', Journal of Communication 27(1), 164168. http://dx.doi.org/10.1111/j.1460-2466.1977.tb01812.x 
Swartley, W.M., 1997, 'Unexpected banquet people', in V.G. Shillington (ed.), Jesus and his parables: Interpreting the parables of Jesus today, pp. 177-190, T\&T Clark, Edinburgh.

Taussig, H., 2009, In the beginning was the meal: Social experimentation \& early Christian identity, Minneapolis, Fortress Press.

Timmer, J, 1990, The kingdom equation: A fresh look at the parables of Jesus, CRC Publications, Grand Rapids.

Van Eck, E., 2007, 'Die huwelik in die eerste-eeuse Mediterreense wêreld (II): Huwelik, egbreuk, egskeiding en hertrou', HTS Teologiese Studies/Theological Studies 63(1), 103-128.

Van Eck, E., 2009, 'Interpreting the parables of the Galilean Jesus: A social-scientific approach', HTS Teologiese Studies/Theological Studies 65(1), Art. \#308, 12 pages. http://dx.doi.org/10.4102v65i1.308
Weder, H., 1978, Die Gleichnisse Jesu als Metaphern: Traditions- und redaktionsgeschichtliche Analysen und Interpretationen, Vandenhoeck \& Ruprecht, Göttingen. (FRLANT 120).

Wenham, D., 1989, The parables of Jesus: Pictures of a revolution, Hodder \& Stoughton, London. (The Jesus Library).

Wickham, C., 1998, 'Gossip and resistance among the Medieval peasantry', Past \& Present 160, 3-24. http://dx.doi.org/10.1093/past/160.1.3

Wilson, P.J., 1974, 'Filcher of good names: An enquiry into anthropology and gossip', Man 9(1), 93-102. http://dx.doi.org/10.2307/2800038

Yerkovich, S., 1977, 'Gossiping as a way of speaking', Journal of Communication 27(1), 192-197. http://dx.doi.org/10.1111/j.1460-2466.1977.tb01817.x

Zinovieff, S., 1991, 'Inside out and outside in', Journal of Mediterranean Studies 1(1), 120-134. 